\title{
CULTURAL ADAPTATION OF EDUCATIVE TECHNOLOGY IN HEALTH: STRING LITERATURE WITH A FOCUS ON BREASTFEEDING ${ }^{1}$
}

\author{
Paula Marciana Pinheiro de Oliveira², António Luís Rodrigues Faria de Carvalho ${ }^{3}$, Lorita Marlena Freitag \\ Pagliuca ${ }^{4}$
}

\footnotetext{
${ }^{1}$ Study developed during a Sandwich Doctoral program in Porto, Portugal, with funding from CNPq and CAPES.

${ }^{2}$ Doctoral nursing studant. By graduate program and nursing departament, Universidade Federal do Ceará. CNPQ research. Ceará, Brasil. E-mail: paulamarciana@yahoo.com.br

${ }^{3}$ Ph.D. in Educational Sciences. Professor, Escola Superior de Enfermagem do Porto. Porto, Portugal. E-mail: luiscarvalho@ esenf.pt

${ }^{4}$ Ph.D. in Nursing. Professor, Nursing Department, Universidade Federal do Ceará. CNPq Researcher. Ceará, Brazil. E-mail: pagliuca@ufc.br
}

\begin{abstract}
String literature about breastfeeding was linguistically and culturally adapted to Portugal. Methodological development study, undertaken at Escola Superior de Enfermagem do Porto, Portugal, between March and May 2012, during a "sandwich" doctoral program in Porto. The theoretical framework of Psychometrics was used, organized in three hubs. In this research, the first was adopted, the theoretical hub, that is, previously constructed health education technology was adapted and, for this purpose, assessed by three expert judges. As a result of this adaptation, modifications were made and it was perceived that string literature about breastfeeding is an important health promotion strategy and that, in order to use it, the presence of health professionals for any clarifications is fundamental. In addition, knowledge is needed about the reality and profile of the users with a view to avoiding constraints. Therefore, nursing has adopted this kind of strategies and perceived the positive result of this use.
\end{abstract}

DESCRIPTORS: Technology. Breast feeding. Health education. Literature.

\section{ADAPTAÇÃO CULTURAL DE TECNOLOGIA EDUCATIVA EM SAÚDE: LITERATURA DE CORDEL COM ENFOQUE NA AMAMENTAÇÃO}

\begin{abstract}
RESUMO: Adaptou-se linguística e culturalmente para Portugal a literatura de cordel sobre amamentação. Estudo de desenvolvimento metodológico realizado na Escola Superior de Enfermagem do Porto, em Portugal, de março a maio de 2012, durante estágio de Doutorado Sanduíche em Porto. Utilizou-se referencial teórico da Psicometria, organizado em três polos. Nesta pesquisa aplicou-se o primeiro deles, polo teórico, ou seja, com tecnologia educativa em saúde já construída, foi adaptada e, para tal, avaliada por três juízas especialistas. Como resultado desta adaptação houve modificações e percebeu-se que literatura de cordel sobre amamentação é importante estratégia de promoção da saúde e, para utilizá-la, é essencial a presença de profissionais de saúde para quaisquer esclarecimentos. Além disso, é necessário conhecer a realidade e o perfil das pessoas que vão utilizá-la, de forma a evitar constrangimentos. Assim, a enfermagem tem adotado estratégias como esta e percebido o resultado positivo deste uso.
\end{abstract}

DESCRITORES: Tecnologia. Aleitamento materno. Educação em saúde. Literatura.

\section{ADAPTACIÓN CULTURAL DE TECNOLOGÍA EDUCATIVA EN SALUD: LITERATURA DE CORDEL CON FOCO EN LA LACTANCIA}

RESUMEN: Se adaptó lingüística y culturalmente la Literatura de cordel sobre lactancia materna para Portugal. Estudio en desarrollo metodológico, realizado en la Escola Superior de Enfermagem do Porto, Portugal, entre marzo y mayo del 2012, durante una pasantía de Doctorado en Porto. Fue utilizado el referencial teórico de la Psicometría, organizado en tres polos. En esta investigación, fue aplicado el primero, el teórico, o sea, con tecnología educativa en salud ya construida, adaptada y evaluada por tres jueces especialistas. Como resultado de esta adaptación, fueron efectuadas modificaciones y se percibió que la literatura de cordel sobre lactancia es una estrategia importante de promoción de la salud y que, para utilizarla es fundamental la presencia de profesionales de salud para clarificaciones cualesquiera. Además, se debe conocer la realidad y el perfil de las personas que irán a utilizarla para evitar constreñimientos. Así, la enfermería ha adoptado estrategias como esta y ha percibido el resultado positivo de este uso.

DESCRIPTORES: Tecnología. Lactancia materna. Educación en salud. Literatura. 


\section{INTRODUCION}

Today, Health Technology Assessment (HTA) has been established but is still evolving in some countries, mainly in developed ones. Many governments in Eastern Europe have already adopted this strategy. ${ }^{1}$ HTA is defined as a continuous process to study the long and short-term consequences of using a certain technology. The assessment of health technologies presupposes admitting that the health effects are not limited to cure or comfort, but affect aspects of human life and its relations with the family, work and society. Health technologies are understood as medicines, medical procedures, equipment, resources, besides health care programs, such as nutritional counseling. ${ }^{2}$

In a paper aimed as assessing health technologies for the blind, the authors reported that this strategy reinforces the role of nurses as health educators committed to the promotion of their clients' quality of life and health. According to them, it is the duty of health professionals to take care of and promote the health of the entire population. ${ }^{3}$ Health technology assessment is clearly important and necessary for the purpose of health promotion and effective care delivery.

In this study, carried out during a "sandwich" doctoral program in Portugal, the decision was made to use this strategy. Therefore, while in Brazil, an educative technology in health was elaborated and validated about breastfeeding. This string literature was presented in categories, discussed in the light of the theoretical reference frameworks related to the theme: 1) Composition of breast milk; 2) Myths and taboos; 3) Professional, family and breastfeeding; 4) Advantages of breastfeeding for the child; 5) Advantages of breastfeeding for the mother and family; and 6) Communication in health.

In this study, in turn, the string literature was adapted to the Portuguese reality. As the strategy is both distinct and innovative, a method that differs from the commonly used manuals, pamphlets and folders, and as it originated on the Iberian Peninsula, the adaptation for possible uses with Portuguese people is curious with a view to health promotion about breastfeeding. Elaborated in a rhymed and playful manner, it can be considered attractive. This communication form was taken to the Brazilian Northeast at the end of the $19^{\text {th }}$ century, where it became known and flourished. It is a communication vehicle and, for a long time, it was responsible for the literacy of thousands of
Northeastern people. In many cases, the booklets were the only type of reading the rural population had access to. It could be part of the material used in primary or secondary schools or in colleges. ${ }^{4}$

Several themes are addressed in string literature, including health. In the latter area, the themes found include dengue fever, HIV/aids, breastfeeding, among others. ${ }^{5}$ Breastfeeding is the theme discussed in this study. Although scientific evidence demonstrates the importance and essential role of breastfeeding when compared to other forms of feeding small children, and despite the efforts of Brazilian and international entities, breastfeeding and particularly exclusive breastfeeding rates in Brazil remain below recommended levels. ${ }^{6}$

In Portugal, the number of children who receive breastfeeding is high, but most of the mothers give up breastfeeding during the infant's first month of life. This finding justifies the elaboration and practice of measures to promote more successful breastfeeding in that country. Studies undertaken in Portugal suggest that breastfeeding evolved in a way similar to other European countries. Consequently, the industrialization, the Second World War, the widespread dissemination of female work, the loss of the expanded family and the publicity of industries producing formulas provoked a reduction in the incidence and prevalence rates of breastfeeding as from the 1930/40's. At the end of the 1970's, the dissemination of the importance and benefits of mother's milk led to a return to breastfeeding, mainly among more informed women. Although gradual, this step did happen. ${ }^{7}$

The above reveals that breastfeeding is relevant and necessary. In this perspective, health professionals play a fundamental role. They are responsible for identifying and understanding the breastfeeding process in different contexts, including the sociocultural and family spheres and, in that sense, for assisting both mothers/ children and their families. There is an urgent need to seek strategies to interact with the population in order to inform them about the importance of adopting a healthy breastfeeding practice. Hence, the professionals should be prepared to deliver effective, solidary, holistic and contextualized care; it is essential to respect each woman's knowledge, experience and life history and help her to overcome fears, difficulties and insecurities. ${ }^{8}$

As mentioned, the objective was to linguistically and culturally adapt string literature about breastfeeding to Portugal. 


\section{METHODS}

Methodological development study with a qualitative approach, undertaken at Escola Superior de Enfermagem do Porto (ESEP) between March and May 2012, during a "sandwich" doctoral program in Porto. The theoretical reference framework of Psychometrics was used, organized in three hubs: theoretical, empirical and analytic. In this study, the theoretical hub was applied through six steps: definition of the psychological object (for us the educative object), its characteristics or attributes, dimensionalities, definition of the construct, implementation of the construct and theoretical analysis of the items. ${ }^{9}$

Initially, the educative object was defined, an educative technology in health, and its properties, activities that were implemented in an earlier study. ${ }^{10}$ After elaborating the technology, the items were constructed to assess that object, that is, the instrument to assess the technology was developed. ${ }^{10}$

To adapt the content of the technology (string literature about breastfeeding) in Portugal, first, adjustments were made in the educative technology to adapt it to the Portuguese reality. Therefore, these adaptations were elaborated with the help of an expert in the area. Next, three judges were selected, who were also content experts, in order to validate the technology and approve its availability as an educative and health promotion strategy. For the expert assessment, a meeting was scheduled, in which the experts and researchers participated. The suggestions for this purpose were described inside the booklet. For the assessment, an instrument was also used, which will be described next. Then, after adjusting the technology, it was delivered to the judges for the sake of correction and completion of the assessment instrument.

To select and invite the group of content judges, experts in maternal, child and community health were chosen, who held a Ph.D. and were responsible for post-graduate research and education in these areas, demonstrating their experience with the theme and contribution to the assessment and construction of the technology. These areas (maternal, infant and community health) were chosen as they are directly related to the study object.

As the theoretical reference framework proposes, ${ }^{9}$ it is fundamental to assess what is under construction, as the opinion of other people can guarantee the validity of what was elaborated.
The content assessment discussed here was aimed at describing the relevance, coherence and clarity of the topics highlighted in the technology and further clarifications.

The assessment instrument of the content judges is divided in two parts. In the first, the aim was to identify them, so as to allow the researcher to know the profile of the respondents. The second part addressed three topics. The first topic, objective, emphasized the composition of breast milk, doubts on myths and taboos, importance of the father, family and professional, advantages of breastfeeding for the mothers, health communication, encouragement of breastfeeding, behavioral changes and attitudes and stimulus at institutions that encourage breastfeeding.

The second topic in the assessment instrument, structure and presentation, indicated the following items: appropriateness of the educative technology to the proposed age range, to women and men, the scientific correctness of the information, the absence of discrimination and prejudice, specific language for the target public, clear information and understandable terms, appropriate size of the text, logical order of the proposed content and existence of inter-relation among the concepts presented in the text.

The third topic of the assessment instrument, relevance, showed whether the technology illustrated a key aspect that needed reinforcement and whether it permitted the transfer and generalization of the learning in different context (hospital, residential and outpatient); in addition, clarifications to the target public were included, addressing aspects of breastfeeding practice, encouragement of breastfeeding and the presence of topics needed to provide clarifications to the family as a whole.

To score the technology, a five-point Likert scale was used in the instrument, in which one represented the lowest and five the highest score. Scores four and five were considered as positive assessment, emphasizing the elaboration of adjustments in the technology as soon as the relevant suggestions had been considered.

Concerning the presentation and analysis of the data, these were systematically organized in tables to clarify the assessment of the technology based on the scientific literature related to the theme.

Ethical aspects were complied with and, in this perspective, non-maleficence, beneficence, au- 
tonomy and justice were respected, as determined for research involving human beings. In addition, the board of the institution gave its authorization to develop the research. For the sake of the study, a declaration authorizing its accomplishment was accepted, as there exists no Research Ethics Committee in the country. Nevertheless, the full project was approved in Brazil under number 21/09. In order not to reveal the judges' assessment data and in compliance with ethical guidelines, the members of the expert group were identified as $\mathrm{J} 1, \mathrm{~J} 2$ and $\mathrm{J} 3$.

\section{RESULTS}

To assess the educative technology, three judges were selected, characterized by the following profiles: two aged 50 years (J1 and J2) and one aged 57 years (J3). One of the judges (J1) held an undergraduate, Master's and Ph.D. in nursing; another judge (J2) held an undergraduate in Child Health and Pediatric Nursing, a Master's degree in Nursing Sciences and a Ph.D. in Philosophical Sciences. The third judge (J3), in turn, held an undergraduate in Pedagogics Applied to Nursing Teaching and a Master's and Ph.D. in Educational Sciences. As regards the time of experience at their current employment institution, they had been active for 20, 23 and 24 years, respectively.

As mentioned, before the judges' assessment, some adjustments were made with the help of an expert in the area. Verses were excluded about crossed breastfeeding and the milk bank, as these situations do not exist in Portugal. In addition, the linguistic adaptation of the text was done, replacing some terms, such as "cancer" by "cancro", "suco" by "sumo", "mamadeira" by "biberão", "mamãe" by "mama" or "mãe" and so on. After this step, for the actually assessment of the strategy during a meeting with the three judges, various adjustments were discussed and the corrections were made in the technology itself. The changes were accepted and further alterations were made, which had not been identified until then. Besides the linguistic adaptations, one verse was re-elaborated as the judges found it mistaken and confusing.

All of the judges were instructed to indicate the adjustments inside the technology, as well as to complete the assessment instrument. Relevant suggestions were accepted, even when coming from a minority, and submitted to a new assessment.

The following table displays the first assessment of the first topic by the content judges.

Table 1 - Content experts' assessment of items in topic 1, objectives, of the instrument. Porto, 2012

\begin{tabular}{|c|c|c|c|}
\hline \multirow[t]{2}{*}{ Item } & & \multicolumn{2}{|c|}{ Assessment } \\
\hline & & 4 & 5 \\
\hline 1.1 & $\begin{array}{l}\text { Pictures aspects of the composition } \\
\text { of breast milk }\end{array}$ & 2 & 1 \\
\hline 1.2 & $\begin{array}{l}\text { Clarifies doubts about myths and } \\
\text { taboos }\end{array}$ & 2 & 1 \\
\hline 1.3 & $\begin{array}{l}\text { Is able to highlight the importance of } \\
\text { the father, family and professional }\end{array}$ & 2 & 1 \\
\hline 1.4 & $\begin{array}{l}\text { Highlights advantages of breast- } \\
\text { feeding for the child }\end{array}$ & - & 3 \\
\hline 1.5 & $\begin{array}{l}\text { Highlights advantages of breast- } \\
\text { feeding for the mother }\end{array}$ & - & 3 \\
\hline 1.6 & $\begin{array}{l}\text { Addresses communication in } \\
\text { health }\end{array}$ & 2 & 1 \\
\hline 1.7 & $\begin{array}{l}\text { Addresses topics of breastfeeding } \\
\text { encouragement }\end{array}$ & 2 & 1 \\
\hline & $\begin{array}{l}\text { Attempts to promote a behavioral } \\
\text { and attitude change }\end{array}$ & 1 & 2 \\
\hline 1.9 & $\begin{array}{l}\text { Attempts to attend to the objectives } \\
\text { of the institutions that work with } \\
\text { breastfeeding }\end{array}$ & 2 & 1 \\
\hline
\end{tabular}

One judge scored the discussion of the promotion of behavioral and attitude change (1.8) and clarified: according to the United Nations Children's Fund (UNICEF), successful breastfeeding demands a combination of three factors: the decision to breastfeed, the establishment of lactation and breastfeeding support (J1).

In table 2, the assessments related to the second topic are summarized.

Although two judges attributed score four the appropriateness of the educative technology to the proposed age range (over 18 years) (2.1), this item only received the following comment: the person can be over 18 and have the cognitive development of a younger person (J1). 
Table 2 - Content experts' assessment of items in topic 2, structure and presentation, of the instrument. Porto, 2012

\begin{tabular}{|c|c|c|}
\hline \multirow[t]{2}{*}{ Item } & \multicolumn{2}{|c|}{ Assessment } \\
\hline & 4 & 5 \\
\hline $\begin{array}{l}\text { 2.1 The technology is appropriate to the } \\
\text { proposed age range (over } 18 \text { years) }\end{array}$ & 2 & 1 \\
\hline $\begin{array}{l}\text { 2.2 The technology is appropriate to } \\
\text { women and men }\end{array}$ & - & 3 \\
\hline $\begin{array}{l}\text { 2.3 The information is scientifically } \\
\text { correct }\end{array}$ & - & 3 \\
\hline 2.4 Free from discrimination or prejudice & - & 3 \\
\hline $\begin{array}{l}\text { 2.5 The language corresponds to the } \\
\text { target public }\end{array}$ & - & 1 \\
\hline $\begin{array}{l}\text { 2.6 The information is clear and the } \\
\text { terms are understandable }\end{array}$ & 3 & - \\
\hline 2.7 The text size is appropriate & 1 & 2 \\
\hline $\begin{array}{l}\text { 2.8 Logical sequence of the proposed } \\
\text { content }\end{array}$ & 1 & 2 \\
\hline $\begin{array}{l}2.9 \text { Interrelation among the concepts } \\
\text { presented in the text }\end{array}$ & 1 & 2 \\
\hline
\end{tabular}

Concerning the language appropriate to the target public (2.5), only one judge answered; the remainder provided observations in a different manner: I do not know the sociodemographic characteristics of the target public (J1); the characteristics of the target public are not known yet, which is why I haven't answered the item (J2).

In the topic that assesses whether the information was clear and the terms understandable (2.6), the following stood out: e.g. p. 5: using the bottle increases, many mothers work and milk and store it in the bottle; $p$. 7: it avoids hemorrhage because it helps the contraction - of what? (J1); needs explanation from health professionals (J3).

As perceived in this specific item, J1's considerations are in accordance with J3's. According to both, some information needs complementation from a health professional.

For the sake of illustration, in table 3, the assessment of the third topic is displayed.

As shown in table 3, one judge did not answer the item related to whether the technology permits the transfer and generalization of learning in different contexts (hospital and domestic) (3.2).
Table 3 - Content experts' assessment of items in topic 2, relevance, of the instrument. Porto, 2012

\begin{tabular}{|c|c|c|}
\hline \multirow[t]{2}{*}{ Item } & \multicolumn{2}{|c|}{ Assessment } \\
\hline & 4 & 5 \\
\hline $\begin{array}{l}\text { 3.1 The technology illustrates a key } \\
\text { aspect that should be reinforced }\end{array}$ & & 3 \\
\hline $\begin{array}{l}\text { 3.2 The technology can permit the } \\
\text { transfer and generalization of } \\
\text { learning in different contexts (hos- } \\
\text { pital and domestic) }\end{array}$ & 1 & 1 \\
\hline $\begin{array}{l}\text { 3.3 The technology clarifies issues } \\
\text { related to breastfeeding practice to } \\
\text { the public }\end{array}$ & - & 3 \\
\hline $\begin{array}{l}\text { 3.4 The technology encourages breast- } \\
\text { feeding }\end{array}$ & - & 3 \\
\hline $\begin{array}{l}\text { 3.5 The technology clarifies topics need- } \\
\text { ed to inform the family as a whole }\end{array}$ & - & 3 \\
\hline
\end{tabular}

At the end of the instrument, in the space reserved for general comments and suggestions, one judge considered: I believe this technique should be used with caution in the target public as, in my perspective, there is a risk of being interpreted as childlike in populations of medium/high sociocultural level. Therefore, I suggest an analysis of the sociocultural characteristics and age of the participants in the validation of the instrument/technique (J2).

After making the necessary adjustments, the string literature totaled 39 verses, presented on ten pages. The topics still addressed the composition of breast milk, myths and taboos the mothers found, the importance of the professional, family and breastfeeding, advantages of breastfeeding for the child, advantages of breastfeeding for the mother and family and the importance of health communication.

\section{DISCUSSION}

As evidenced in the results, the technology was modified to adapt it to the Portuguese reality. Some terms were changed for the sake of an easier understanding of the educative technology by the Portuguese.

According to the literature, the cultural and social context the woman belongs to interfere in the motivation to breastfeed. This process is complex and involves many possible influential variables, depending on the country, in the same 
country among groups of people, among individuals, based on social pressure, the collective imaginary and personal opinions. ${ }^{11}$

In a study that used the same educative technology, in Brazil, various suggestions were provided for substitution and explanation of terms that were considered inappropriate and confusing and, at the same time, the addition of important information was proposed. Some terms were replaced for the sake of an easier understanding. ${ }^{12}$

The cultural adaptation is a decisive aspect as, with a view to successful breastfeeding, the mother needs to receive understandable information about this process, related to biological, immunological and physiological aspects, as well as aspects related to the breastfeeding technique. ${ }^{13} \mathrm{It}$ is undeniable that this adaptation is fundamental, as the orientations health professionals provide can neither be different nor conflicting. Otherwise, they could increase the mothers' anxiety and anguish. ${ }^{14}$ An educative technology for the purpose of health promotion and education should be adapted to the reality of the place, describing and clarifying what the literature translates. That is effective and objectively important.

As described in the literature, to achieve a successful breastfeeding process, the breastfeeding culture needs to be elaborated and the population needs education about its advantages and the meaning of this practice. It is essential to integrate interventions in accordance with the most recent scientific knowledge, to offer support to the mothers before, during and after this act, to create conditions in the workplace, to enforce the policies and propose new laws with a view to improving this practice. It is fundamental to counter inappropriate publicity for formula milk, as well as the use of bottles and pacifiers. ${ }^{15}$ As mentioned, the content of the educative technology in this study, a string literature about breastfeeding, was adapted and assessed by Portuguese judges. The assessment was positive and modifications were made in response to the judges' suggestions. In the first topic, objectives, one of the judges assessed the item behavior and attitude change and attributed score four, which is considered excellent. As she justified, a successful breastfeeding process demands not only educative technologies, but also the decision to breastfeed, the establishment of lactation and breastfeeding support.

In order to decide to breastfeed, clarifications about the importance and advantages of this process for mothers and infants are fundamental.
Breastfeeding support is needed. In this perspective, it is fundamental for health professionals who listen and try to understand how the mothers feel to try and help to decide what is best for them, what to do and how to gain self-confidence. Their function is to help the mothers to experience the breastfeeding process healthily, in biological as well as sensory and psychic terms. ${ }^{16}$ In this context, it is essential to clarify the difference between advising and counseling. While advising involves telling the person what to do, counseling is a form of professional activity in which the professionals should listen to and understand the mothers and, using their scientific knowledge, offer help in order to grant them the opportunity to plan, decide and get strengthened in order to deal with pressure. This increases their self-confidence and self-esteem. ${ }^{17}$

Support for couples going through the lactation process should be ongoing throughout the breastfeeding period and is decisive to help and establish the lactation. For the purpose of competent activities with the clients, the nurses should be up-to-date in their knowledge and conducts. ${ }^{18}$ Therefore, the use of appropriate technologies for each binomial is urgent with a view to effective and high-quality care delivery. ${ }^{19}$

To establish the breastfeeding process, the infants need to be given time to explore the breast, until they decide to open their mouth and place their tongue in the appropriate position, and then taken closer to the breast, holding them by the back instead of the head. As evidenced, many mothers bend over their babies and remain inclined while breastfeeding. This position is not comfortable for the mother and may cause back pain in the future. ${ }^{20}$

Therefore, information is always necessary, to give an example, almost all mothers who are informed about breastfeeding through a preparatory course for birth or any other kind of breastfeeding support tend to start this practice and maintain it longer. After they are discharged, the mothers should continue receiving medical and nursing care during the first days of breastfeeding, as that is when breast-related problems come up, such as mastitis, breast engorgement or painful nipples. In addition, that is when the alterations characteristic of newborn infants are manifested, including excessive crying, lack of growth, colic and sleep problems, factors that predispose to the abandonment of breastfeeding. Hence, during the first postpartum days, support to the mothers and families is fundamental. ${ }^{21}$ 
According to a study, breastfeeding should start in the first two hours of life, while still in the delivery room, provided that mother and infant are in good health conditions. This favors the contact between both and the start of effective breast milk suction, positively interfering in the longer length of breastfeeding and provoking long-term positive effects on mother-infant interaction, as the child becomes more sociable, smiles more and cries less. Children who were separated from their mothers early are significantly more irritable and, latter, a less affective relation is demonstrated. ${ }^{22}$ In this context, it is emphasized that nursing interventions need to be elaborated, mainly using health education during prenatal care and even in the delivery room, so that these clarifications to the mothers about the relevance of early breastfeeding can entail positive consequences. ${ }^{19}$

As regards topics two and three of the research assessment, about the structure and presentation and relevance of breastfeeding, the judges' observations highlight the relevance of informing the target population with a view to truly having an appropriate answer about the effectiveness or not of health promotion with the use of the elaborated educative technology. The discussions are pertinent and, in future studies, this health education strategy needs to be used and the ideal public for the application of this material needs to be perceived. The judges are curious to find out what public it will better adapt to. One of the judges indicated the need for the presence of professionals together with other people when using the health promotion technology. This is significant as, although popular language is adopted in the technology, it also contains technical terms that cannot be excluded so as not to cut down on its scientific merit.

Concerning the general comments and suggestions described in the instrument, one judge expressed the importance of applying the technology to a specific group of people so as not to infantilize it. This opinion supports the description of the reference framework used ${ }^{23}$ when referring to the importance of a pilot test in studies that employ technologies and instrument with specific populations and different social and demographic characteristics. The intent is to get to know and identify the clients the health promotion and education technology is aimed out, without any mistaken interpretations.

In an integrative literature review about the types of technologies nurses can develop or adopt for the purpose of breastfeeding promotion, it was verified that, in most cases, nursing has used hard technology as a strategy to facilitate the promotion of breastfeeding. The use and development of light and mainly light-hard technologies should clearly be stimulated. Nevertheless, the light-hard technology was not used in any of the articles. Therefore, this type needs to be implemented in nursing care, as theories, methods and processes provide safer and more effective foundations for the interventions made in their professional practice. As each person has his/her particularities in the teachinglearning process and as individual strategies exist to understand each subject, technologies need to be elaborated and use that effectively affect as many people as possible in the best possible manner. ${ }^{19}$

\section{FINAL CONSIDERATIONS}

The result of the validation of this educative technology, string literature about breastfeeding, revealed that the strategy is important and interesting for the purpose of health promotion but, to use it, according to one judge, the presence of health professionals for any clarifications is essential. In addition, the reality and profile of the people who are going to use it needs to be known in order to avoid constraints. Therefore, further research is suggested, involving groups of people in order to identify specific needs.

In this perspective, as evidenced, educative technologies in health need to be elaborated and disseminated to spread information the population needs about different topics. Specifically breastfeeding is an act of love that offers advantages for mothers and children and, therefore, strategies need to be constructed and used to increase the breastfeeding habit each day in different countries. Nursing has adopted various strategies of this kind and has perceived that the result of this use is positive. As a profession that is present together with the people on many occasions, it can get to know the reality of the attended clients times and thus adapt it, positively influencing the dissemination of information.

As it works with rhymes, string literature can be considered an interesting means of health promotion and education for the population. It can be used with different themes.

\section{REFERENCES}

1. Nita ME, Secoli SR, Nobre M, Ono-Nita SK. Métodos de pesquisa em avaliação de tecnologia em saúde. Arq Gastroenterol. 2009 Out-Dez; 46(4):252-5. 
2. Ministério da Saúde (BR). Secretaria-Executiva, Área de Economia da Saúde e Desenvolvimento. Avaliação de tecnologias em saúde: ferramentas para a gestão do Sistema Único de Saúde. Brasília (DF): MS; 2009.

3. Cezario KG, Pagliuca LMF. Tecnologia assistiva em saúde para cegos: enfoque na prevenção de drogas. Esc Anna Nery Rev Enferm. 2007 Dez; 11(4):677-81.

4. Lima AV. Acorda cordel na sala de aula. Fortaleza (CE): Tupynamquim; 2006.

5. Pagliuca LMF, Oliveira PMP, Rebouças CBA, Galvão MTG. Literatura de cordel: veículo de comunicação e educação em saúde. Texto Contexto Enferm. 2007 Out-Dez; 16(4):662-70.

6. Ministério da Saúde (BR). Saúde da criança: aleitamento materno e alimentação complementar. Brasília (DF): MS; 2009.

7. Nelas PA, Ferreira M, Duarte JC. Motivação para amamentação: construção de um instrumento de medida. Rev Referência. 2008 Jun; 2(6):39-56.

8. Castro LMCP, Araújo LDS. Aspectos socioculturais da amamentação. In: Castro LMCP, Araújo LDS. Aleitamento materno: manual prático. $2^{\mathrm{a}} \mathrm{ed}$. Londrina (PR): PML; 2006. p. 41-9.

9. Pasquali L. Instrumentação psicológica: fundamentos e práticas. Porto Alegre (RS): Artmed; 2010.

10. Oliveira PMP, Rebouças CBA, Pagliuca LMF. Literatura de cordel como meio de promoção para o aleitamento materno. Esc Anna Nery Rev Enferm. 2008 Jun; 12(2):217-23.

11. Galvão DG. A decisão de amamentar: um processo complexo ainda mal conhecido. Sinais Vitais. 2002; (41):49-51.

12. Oliveira PMP. Avaliação de uma tecnologia assistiva sobre amamentação para pessoas cegas [dissertação]. Fortaleza: Uiversidade Federal do Ceará, Programa de Pós-Graduação em Enfermagem; 2009.

13. Carvalho GD. Amamentação e o sistema estomatognático. In: Carvalho MR, Tamez RN. Amamentação: bases científicas para a prática profissional. $2^{a}$ ed. Rio de Janeiro (RJ): Guanabara Koogan; 2005. p. 11-24.
14. Pereira MA, Levy L, Matos ME, Calheiros JM. Influência da correção da pega correta: resultados de um estudo experimental. Rev Referência. 2008 Jun; 2(6):27-38.

15. Giugliani ERJ. Amamentação exclusiva e sua promoção. In: Carvalho MR, Tamez RN. Amamentação: bases científicas para a prática profissional. $2^{\mathrm{a}}$ ed. Rio de Janeiro (RJ): Guanabara Koogan; 2005. p. 11-24.

16. Galvão DG. Formação em aleitamento materno e suas repercussões na prática clínica. Rev Bras Enferm. 2011 Mar-Abr; 64(2):308-14.

17. Bueno LGS, Teruya KM. Aconselhamento em amamentação e sua prática. J Pediatr. 2004; 80(5Supl):126-30.

18. Arantes CIS, Montrone AVG, Milione DB. Concepções e conhecimento de sobre amamentação de profissionais da atenção básica à saúde. Rev Eletr Enferm [online]. 2008 [acesso 2012 Jun 01]; 10(4):93344. Disponível em: http:/ / www.fen.ufg.br/revista/ v10/n4/pdf/v10n4a06.pdf

19. Joventino ES, Dodt RCM, Araujo TL, Cardoso MVLML, Silva VM, Ximenes LB. Tecnologias de enfermagem para promoção do aleitamento materno: revisão integrativa da literatura. Rev Gaúcha Enferm. 2011 Mar; 32(1):176-84.

20. Gonzales C. Manual prático de lactancia materna. Barcelona (ES): ACPAM; 2004.

21. Braga LC. Aleitamento materno: uma prática de educação para a saúde no âmbito da enfermagem obstétrica [dissertação]. Vila Real: Universidade de Trás-os-Montes e Alto Douro, Programa de PósGraduação em Educação; 2006.

22. Bystrova K, Ivanova V, Edhborg M, Matthiesen AS, Ransjö-Arvidson AB, Mukhamedrakhimov R, et al. Early contact versus separation: effects on mother infant interaction one year later. Birth. 2009 Jun; 36(2):97-109.

23. Pasquali L. Instrumentos psicológicos: manual prático de elaboração. Brasília (DF): Lab PAM/ IBAPP; 1999. 